\title{
The effects of second-hand smoke on biological processes important in atherogenesis
}

\author{
Hongwei Yuan¹, Lina S Wong2, Monideepa Bhattacharya ${ }^{2}$, Chongze $\mathrm{Ma}^{2}$, \\ Mohammed Zafarani², Min $\mathrm{YaO}^{2}$, Matthias Schneider ${ }^{3}$, Robert E Pitas ${ }^{3}$ and \\ Manuela Martins-Green*1,2
}

\begin{abstract}
Address: ${ }^{1}$ Graduate Program in Cell, Molecular and Developmental Biology, University of California, Riverside, Riverside, California, USA ${ }^{2}$ Department of Cell Biology and Neuroscience, University of California, Riverside, Riverside, California, USA and ${ }^{3}$ Gladstone Institute of Cardiovascular Disease, University of California, San Francisco, San Francisco, California, USA
\end{abstract}

Email: Hongwei Yuan - hyuan001@student.ucr.edu; Lina S Wong - linawong1@yahoo.com; Monideepa Bhattacharya - mbhat001@student.ucr.edu; Chongze Ma - cma004@student.ucr.edu; Mohammed Zafarani -mo5_@hotmail.com; Min Yao - minyao@ucr.edu; Matthias Schneider - mschneider@lexgen.com; Robert E Pitas - rpitas@gladstone.ucsf.edu; Manuela MartinsGreen* - manuela.martins@ucr.edu

* Corresponding author

Published: 08 January 2007

BMC Cardiovascular Disorders 2007, 7:1 doi:10.1186/147|-226I-7-I

This article is available from: http://www.biomedcentral.com/|47|-2261/7//

(C) 2007 Yuan et al; licensee BioMed Central Ltd.

This is an Open Access article distributed under the terms of the Creative Commons Attribution License (http://creativecommons.org/licenses/by/2.0), which permits unrestricted use, distribution, and reproduction in any medium, provided the original work is properly cited.
Received: 27 August 2006

Accepted: 08 January 2007

\begin{abstract}
Background: Atherosclerosis is the leading cause of death in western societies and cigarette smoke is among the factors that strongly contribute to the development of this disease. The early events in atherogenesis are stimulated on the one hand by cytokines that chemoattract leukocytes and on the other hand by decrease in circulating molecules that protect endothelial cells (ECs) from injury. Here we focus our studies on the effects of "second-hand" smoke on atherogenesis.

Methods: To perform these studies, a smoking system that closely simulates exposure of humans to secondhand smoke was developed and a mouse model system transgenic for human apoB 100 was used. These mice have moderate lipid levels that closely mimic human conditions that lead to atherosclerotic plaque formation.

Results: "Second-hand" cigarette smoke decreases plasma high density lipoprotein levels in the blood and also decreases the ratios between high density lipoprotein and low density lipoprotein, high density lipoprotein and triglyceride, and high density lipoprotein and total cholesterol. This change in lipid profiles causes not only more lipid accumulation in the aorta but also lipid deposition in many of the smaller vessels of the heart and in hepatocytes. In addition, mice exposed to smoke have increased levels of Monocyte Chemoattractant Protein-I in circulation and in the heart/aorta tissue, have increased macrophages in the arterial walls, and have decreased levels of adiponectin, an EC-protective protein. Also, cytokine arrays revealed that mice exposed to smoke do not undergo the switch from the pro-inflammatory cytokine profile (that develops when the mice are initially exposed to second-hand smoke) to the adaptive response. Furthermore, triglyceride levels increase significantly in the liver of smoke-exposed mice.
\end{abstract}

Conclusion: Long-term exposure to "second-hand" smoke creates a state of permanent inflammation and an imbalance in the lipid profile that leads to lipid accumulation in the liver and in the blood vessels of the heart and aorta. The former potentially can lead to non-alcoholic fatty liver disease and the latter to heart attacks. 


\section{Background}

Atherosclerosis is an inflammatory disease that accounts for nearly $50 \%$ of deaths in western societies [1]. Initiation of atherosclerotic plaque formation is a complex process. It involves secretion of chemokines such as the Monocyte Chemoattractant Protein-1 (MCP-1) [1-4] and expression of adhesion molecules on the surface of monocytes and endothelial cells [5-7]. Circulating monocytes are recruited to sites of injured endothelial cells, adhere to them, and migrate into the subendothelial space. Monocytes in the arterial wall differentiate into activated macrophages that are efficient scavengers of oxidized low density lipoprotein (LDL). When exposed to large amounts of oxidized LDL, these macrophages accumulate large amounts of cholesteryl esters in lipid droplets and become "foam cells" that form "fatty streaks", the precursors of more complicated atherosclerotic plaques $[8,9]$.

Many factors can lead to initiation of atherosclerosis. In the Framingham heart study [10-12], the best-known prospective investigation that established the risk factors for coronary heart disease and peripheral vascular disease, smoking was identified as one of the major risk factors for the development of atherosclerosis. Cigarette smoke is a complex mixture of more than 4,700 chemical constituents distributed in particulate and gaseous phases, including nicotine, aromatic hydrocarbons, sterols and oxygenated isoprenoid compounds, aldehydes, nitriles, cyclic ethers, and sulfur compounds [13]. Cigarette smoking accelerates atherosclerosis in the coronary arteries, the aorta, the carotid and cerebral arteries, and the large arteries in the peripheral circulation. Toxic substances present in cigarette smoke build up in the areas of curvature and branching of arteries, injuring the endothelium [2,14]. Furthermore, epidemiological studies have shown that both active and passive cigarette smoking increase the risk of atherogenesis [9]. In spite of all the evidence that cigarette smoke stimulates atherogenesis and lipoprotein oxidation may play an important role [9], very little is known about the biological processes induced by smoke that contribute to increased cardiovascular disease.

Chemokines are small (8-10 kDa) stress-response proteins expressed when organisms or cells are exposed to an insult. The effects of cigarette smoke on atherosclerosis are no exception. MSW (mainstream whole, "first-hand") smoke and SSW (sidestream whole, major component of "second-hand" smoke) smoke recently have been shown to stimulate human fibroblasts to express several chemokines, including MCP-1 [15-17]. This chemokine plays a key role in atherosclerotic lesion formation [18-23]. However, studies to determine the effects of cigarette smoke on atherosclerosis have been hampered because of the lack of a stress-free system to expose the mice to smoke. In most of the published studies, when the animals were exposed to smoke, they were confined to a small device without free access to food and water. This invariably put the animals under added stress in addition to that caused by the cigarette smoke [24]. Therefore, for these studies we developed a smoking system that allows the animals being exposed to cigarette smoke to move freely and consume water and food at will. Also important, with this system we can separate and control SSW and MSW exposure. In addition, this system allows for control of smoke dosage.

The most commonly used mouse model systems for studies of atherogenesis are mice deficient in either apolipoprotein E (ApoE -/-) or the low density lipoprotein receptor (LDLR-/-). Whereas these models have the advantage of developing lesions in a short time and are easy to manage, lesion formation occurs under altered physiological conditions, such as hyperlipidemia. The LDLR-/- mice represent a genetic defect that leads to hypercholesterolemia. These mice are excellent to model disease conditions but do not represent well the most common situation in humans, i.e. formation of atherosclerotic lesions under moderate lipidemia. Therefore, to study the effects of SSW on biological processes involved in initiation of plaque formation, human apoB100 transgenic mice [25] fed a high fat diet were used. These animals have moderate hypercholesterolemia, much like most humans that develop atherosclerosis. Our results show that many of the early indicators of plaque initiation are stimulated by SSW in these mice and suggest a mechanism by which SSW accelerates atherogenesis.

\section{Methods \\ Key reagents}

All common chemicals were purchased from Sigma Biochemicals and Fisher Scientific; LDL L-Type test, L-Type HDL-C test, Colesterol C II test, and L-Type TG H test (Waco Diagnostics, Richmond, VA); Tissue-Tek Optimal cutting Temperature (OCT)(Sakura Finetek USA, Torrance, CA); Oil-Red-O (Fisher Scientific). Primary antibodies: Rabbit anti-mouse-MCP-1 (Cell Sciences, Canton, MA); rat anti-mouse F4/80 (Serotec, Oxford, UK); rabbit anti-human myeloperoxidase which cross-reacts with mouse) (Biomeda, Foster City, CA); goat anti-mouse adiponectin (R\&D Systems Minneapolis, MN). Secondary antibodies: chicken anti-rat-Alexa488 (Gift from Dr. Christian Lytle); goat anti-rabbit-FITC (Zymed, South San Francisco, CA); rabbit anti-goat conjugated to HRP (Rockland immunochemicals, Inc., Gilbertsville, PA); goat antirabbit conjugated to HRP for subsequent use with the Super signal West Dura extended duration substrate (Pierce Chemical, Rockford, IL); ECL detection system (Amersham Piscataway, NJ); Vectashield mounting medium (Vector Laboratories, Burlingame, CA); DC protein assay kit (Bio-Rad, Hercules, CA). 


\section{Animal system and diet}

6-8 week old male mice (57BL/6Ntac-TgN(APOB100)) were purchased from Taconic Farms, Inc. [25]. 6-8 week old male apoB100 transgenic mice (apoB100 Leu-Leu) on $57 \mathrm{BL} / 6 \mathrm{SJL}$ background were also used. The latter mice differ from the former in that they over-express human apoB100 without expression of apoB48, due to a mutation in codon 2163 that converted CAA the codon for Gln to CTA the codon for Leu effectively precluding the expression of apoB48 [26]. The mice were maintained in a pathogen-free facility with a 12-hrs light/12-hrs dark cycle and had free access to water and food. The mice were kept on regular diet to adapt to the environment for one week, and then changed to a high fat diet. This diet contains $1.25 \%$ Cholesterol, $15 \%$ cocoa butter, and $0.5 \%$ sodium cholate $[27,28]$ and was purchased from MP Biomedicals, Inc. The mice were put into the smoking experiments a week after switching them to the high fat diet. All animal experiments were conducted in accordance with U.S. Public Health Service/U.S. Department of Agriculture guidelines. Experimental protocols were approved by the University of California Riverside Institutional Animal Care and Use Committee.

\section{Exposure of the animals to smoke}

The cigarettes used in this study (1R3F research grade) were purchased from Kentucky Tobacco Research \& Development Center. A puffer box was used to generate smoke according to FTC guidelines: 1 puff/minute, 3 seconds/puff. Each smoke type was mixed with fresh air before it was puffed through a tube into the small mouse exposure chambers (Teague Enterprise). The air in the chambers was exhausted using a fan (vortex blower). The mice in the smoking groups were exposed to the smoke for 6 hrs/day (10 min smoking with 5 min break), 5 days/ week. Smoke particle concentration in the chamber was maintained at $25 \pm 2 \mathrm{mg} / \mathrm{m}^{3}$ by adjusting the fresh air entering and exhausting from the chamber. Smoke samples taken from each chamber were passed through a filter; the particulate material deposited on the filter was measured by weighing the filter before and after smoke filtration. The vacuum pump gas meter recorded the smoke sample volume passed through the filter. Total particulate matter (TPM) was calculated by dividing the total particle weight trapped on the filter by the volume passed through the filter.

\section{Smoke exposure analysis}

Inhalation of smoke by the mice was monitored by measuring the blood carboxyhemoglobin level according to Griffith et al. [24]. Briefly, $20 \mu \mathrm{l}$ of blood from the mouse was diluted to $20 \mathrm{ml}$ with $0.04 \%$ ammonium hydroxide. The absorbance values at $413 \mathrm{~nm}$ and $420 \mathrm{~nm}$ were determined and the 420/413 ratio was calculated. An increase in this ratio reflects smoke exposure. We also measured and calculated the blood carboxyhemoglobin level. Briefly, $10 \mu \mathrm{l}$ of blood were mixed with freshly prepared sodium dithionite $(2 \mathrm{mg} / \mathrm{ml})$ in $0.01 \mathrm{~mol} / \mathrm{l}$ TRIS (hydroxymethyl) aminomethane solution, and absorption spectra at 420 and $432 \mathrm{~nm}$ were recorded within 2-3 minutes. The concentration of $\mathrm{COHb}$ was calculated using the following equation: Percent $\mathrm{COHb}=100 \times[1-$ $(\mathrm{Ar} \times \mathrm{F} 1)] /[\mathrm{Ar} \times(\mathrm{F} 2-\mathrm{F} 1)-\mathrm{F} 3+1]$, where $\mathrm{Ar}=\mathrm{Abs} 420 \mathrm{~nm} /$ Abs432 nm, F1 $=1.3007, \mathrm{~F} 2=0.4648, \mathrm{~F} 3=2.0526$ according to previously published work $[29,30]$.

\section{Plasma lipid analysis}

Levels of total cholesterol (TC), triglycerides (TG), low density lipoproteins (LDL), and high density lipoproteins (HDL) in plasma were determined by enzymatic assay using commercially available kits (Wako Chemical Co.) and following the instructions given by the company.

\section{Tissue lipid analysis}

After the mouse was sacrificed, its liver was harvested and frozen immediately on dry ice and kept at $-72^{\circ} \mathrm{C}$. Lipids were extracted from about $300 \mathrm{mg}$ liver tissue (wet weight) into $30 \mathrm{ml}$ chloroform: methanol (2:1) according to the method of Folch et al. [31]. Phases were separated by addition of $6 \mathrm{ml} \quad 0.05 \% \quad \mathrm{H}_{2} \mathrm{SO}_{4}$ and aliquots of extracted lipids were mixed with $1 \%$ Triton X-100, dried under a stream of $\mathrm{N}_{2}$, and re-dissolved in water [32]. Commercial kits were used for the specific determination of total cholesterol and triglycerides (WAKO Chemicals USA, Inc., Richmond, VA). The hepatic lipid concentrations were expressed as milligrams of lipids per gram of wet weight.

\section{Lesion analysis}

Mice were fasted for 4 hrs, anesthetized with ketamine and xylazine and were perfused with $10-15 \mathrm{~mL}$ of PBS, pH 7.4 (80 mmHg), followed by $4 \%$ paraformaldehyde for 3-5 minutes [21]. The heart and aorta were removed and fixed for an additional 1-2 hrs in 4\% paraformaldehyde followed by infiltration with $30 \%$ gum sucrose (1\% gum Arabic, 30\% sucrose in PBS) for $24 \mathrm{hrs}$ at $4{ }^{\circ} \mathrm{C}$ and embedded in OCT for sectioning [33]. Briefly, the OCTembedded, frozen aortas were cross-sectioned serially at $10-\mu \mathrm{m}$ thicknesses for a total of $300 \mu \mathrm{m}$ beginning at the base of the aortic valve, where all three leaflets are first visible. Every fourth section for a total of five sections from each animal was stained with Oil-Red O (Fisher scientific company) and counterstained with hematoxylin (Sigma) to identify the lipid-rich lesions. Average lesion sizes of these 5 cross sections were used for morphometric evaluations. Images were captured using a Nikon microscope with camera and scanned into a computer. Quantitation of atherosclerotic lesions was performed using NIH Image software. Results are expressed as percent of the total cross-sectional vessel wall area [21]. 


\section{Immunolabeling}

Sections of the heart and aorta were used for immunostaining for MCP-1 with a primary rabbit anti-mouse polyclonal antibody (Cell Sciences). As secondary antibody, a FITC-labeled goat anti-rabbit IgG was used. For macrophage staining, rat anti-mouse F4/80 antibody (Serotec, undiluted) was used as primary antibody and Alexa Fluor 488-labeled chicken anti-rat antibody was used as secondary antibody. For neutrophil staining, rabbit anti-MPO antibody was used as primary antibody and FITC-labeled goat anti-rabbit IgG was used as secondary antibody. For splenic cell staining, rat anti mouse CD4+, IL-4, or IFN $\gamma$ antibodies (BioLegend) were used as primary antibodies and FITC-labeled goat anti-rat IgG was used as secondary antibody. Quantitation was performed by counting the labeled cells in 3 high-power fields/section of spleen, taking the average and then calculating the ratio. In cell clusters, the number of stained cells was estimated by the size of the cells.

\section{Cytokine antibody array}

Cytokine levels in the plasma were measured using QPlex $^{\mathrm{TM}}$ Mouse Cytokine array (Quansys Biosciences, Utah, USA), which is a fully quantitative ELISA-based test in which each well of a 96 well plate was coated with 16 distinct capture antibodies in a defined array. $30 \mu \mathrm{l}$ of cytokine standard or plasma sample were added into the appropriate wells. After $1 \mathrm{hr}$ incubation, the wells were washed 3 times and probed with streptavidin-HRP for 15 minutes at room temperature. After washing 3 times and adding the substrate, the images were captured by a cooled CCD camera (MicroMAX-1300B, Roper Scientific) and analyzed using the Quansys image analysis software. The concentrations of cytokine were calculated and plotted using the standard curve.

\section{Results}

\section{Cigarette smoking system and calibration}

A system that can be used to administer cigarette smoke to small animals under conditions that minimize stress was developed (Figure 1A). In this system, the MSW (Mainstream whole, "first-hand") and the SSW (Sidestream whole, a major component of "second-hand") smoke generated from a puffer box are distributed to separate smoking chambers. MSW smoke is defined as the smoke inhaled by the smoker, whereas SSW smoke is defined as the smoke emanating from the burning end of the cigarette. For this study, the mouse cages with food and water are introduced into the chamber that receives only SSW; the mice are free to move around and eat and drink at will. Therefore, the mice are exposed only to SSW, the major component of second hand smoke. The dose of smoke in each chamber is controlled by adjusting the intake and exhaust valves (see Materials and Methods). When making the measurements, the filter unit connected to the vac- uum pump gas meter is connected to the smoking chamber, and the smoke sample from the chamber passes through the filter unit. The filter unit holds a special filter paper that can trap particles in the smoke sample. The vacuum pump meter was set to collect sample for $10 \mathrm{~min}$ utes, and the volume of the smoke passed through the filter unit can be calculated from the meter readings of the start and end points. The weight of the filter was determined both before and after each sampling; the weight difference of the filter paper is the weight of particulate matter trapped by the filter. The smoking dose was obtained by calculating the weight of particulate matter per cubic meter of sample in the chamber.

Because second-hand smoke exposure occurs in environments that are usually out of control of the person(s) being exposed, e.g. children and teens of households in which the parents smoke, we decided to focus our studies on the effects of SSW on processes that relate to atherogenesis. As in previous studies [34,35], a smoking dose of $25 \pm 2 \mathrm{mg} / \mathrm{m}^{3}$ total particulate matter (TPM) was used. The mice were exposed to SSW for 6 hours, with 5 minutes break every 10 minutes, the time taken to smoke 1 cigarette. The total exposure thus is 24 cigarettes/day, which is similar to the average number of cigarettes smoked indoors in a typical smoker's home (an average smoker smokes about 1.4 packs or 28 cigarettes/day [36]). To arrive at the dose of $25 \pm 2 \mathrm{mg} / \mathrm{m}^{3}$, the chambers were set at a pressure of 0.42 inches w.c. (water column), which equals $0.104 \mathrm{kPa}$. For the smoking cage used $(19$ in $\times 19$ in $\times 16$ in), the flow rate at this pressure was 28.1 liter/ min. Extra smoke was filtered to reduce air pollution and expelled from the chamber into the fume hood by the blower fan (Figure 1B). To verify that the mice were exposed to cigarette smoke, the blood carboxyhemoglobin (CoHb) level was measured. SSW-exposed animals showed an increased level of blood carboxyhemoglobin, as expected (Figure 1C). COHb levels were significantly higher in mice exposed to CS compared to mice exposed to air $(8.11 \pm 1.08 \%, \mathrm{n}=4$ versus $2.38 \pm 0.16 \%, \mathrm{n}=6$, respectively; $P<0.01)$. The mean $\mathrm{COHb}$ concentrations for nonsmokers were reported to be about $1-2 \%$ and those for smokers about $4-7 \%[37,38]$. In heavy smokers, the $\mathrm{COHb}$ concentration was $12 \%$. In the mice model, the value may be slightly higher, $1.2 \pm 0.8 \%$ versus $12.2 \pm$ $4.9 \%$, respectively [37]. Therefore, the amount of pulmonary stress to the animals was similar to reported studies.

\section{SSW causes changes in lipid physiology}

In patients with cardiovascular disease, the HDL/LDL ratio decreases significantly. A low HDL/LDL cholesterol ratio is an important risk factor for atherosclerosis. HDL participates in reverse cholesterol transport, i.e., it carries cholesterol away from the arteries and other peripheral tissues and back to the liver for excretion from the body. 

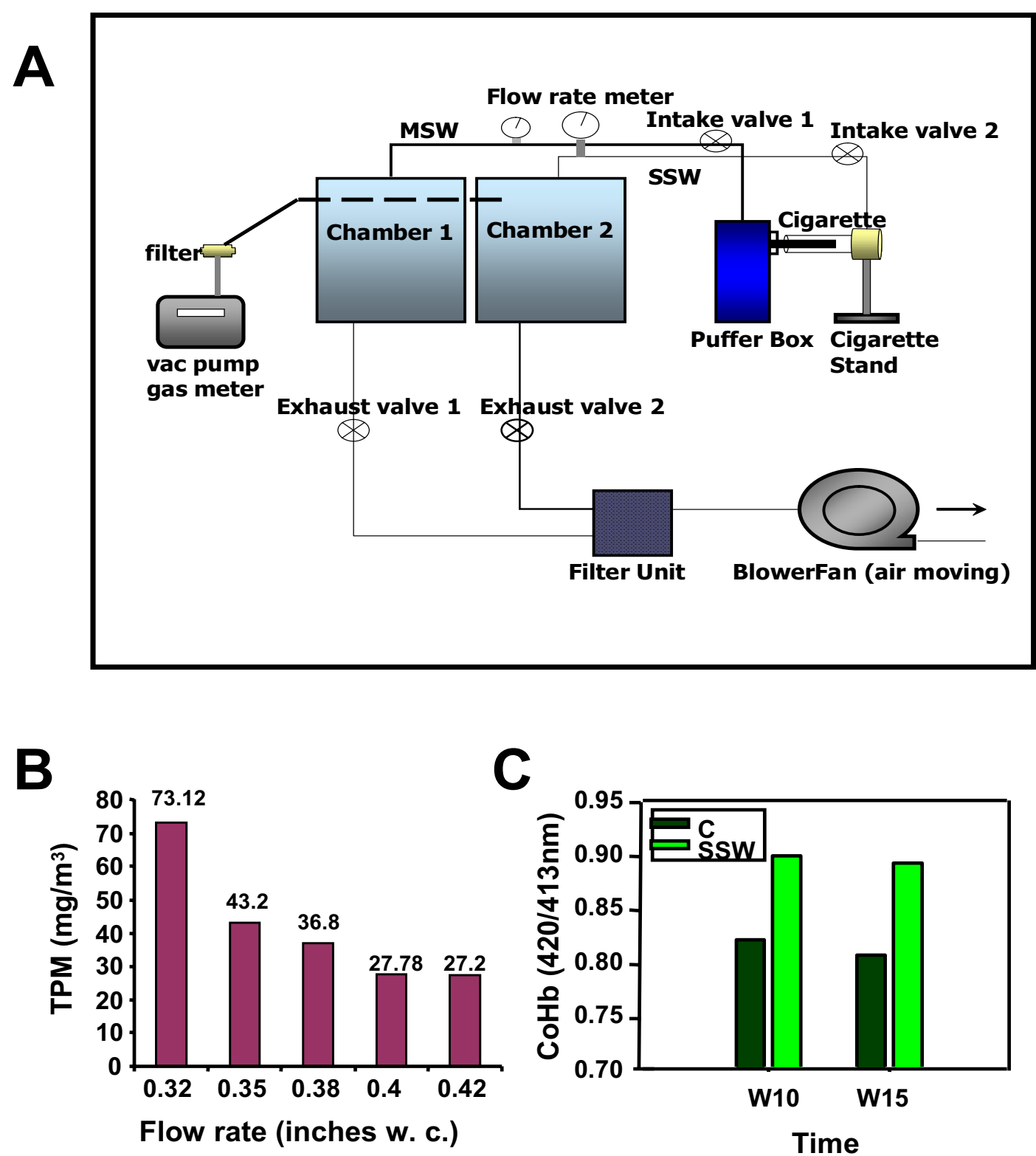

Figure I

Schematic representation of the Smoking System, smoking dose calibration, and effects of cigarette smoke on blood carboxyhemoglobin (CoHb) levels. (A) Schematic representation of the smoking system. Smoke was generated by using a puffer box built by the University of Kentucky [33] and chambers built by Teague Enterprises. Each smoke type can be mixed with fresh air before it was puffed through a tube into the exposure chambers. In this study only the SSW chamber was used. The air and smoke in the chamber were exhausted using a blower fan (air moving fan). A vacuum pump/gas meter was used for dose calibration only. (B) The smoking dose was calibrated to $25 \mathrm{mg} T P M / \mathrm{m}^{3}$ by adjusting the intake and exhaust valves. Smoke samples taken from the SSW chamber were passed through a filter unit; the particulate material deposited onto the filter was measured by weighing the filter before and after smoke filtration. The vacuum pump gas meter recorded the smoke sample volume passed through the filter. Total particulate matter (TPM) was calculated by dividing the total particle weight trapped on the filter by the volume passed through the filter. w.c. = water column. (C) Mice were exposed to SSW smoke for $6 \mathrm{hrs}$ intermittently and blood was drawn to test for carboxyhemoglobin. Blood was treated with ammonium hydroxide, absorbance measured at $420 \mathrm{~nm}$ and $413 \mathrm{~nm}$ and the ratio plotted. $\mathrm{C}=$ control. 
This removes excess cholesterol from plaques, thus minimizing the buildup of cholesterol in the artery walls. SSW smoke decreases the HDL level in the plasma (Figure 2A) and decreases the ratio between HDL and LDL, HDL and triglyceride (TG), and HDL and total cholesterol (TC) (Figure 2B-D). The total plasma cholesterol level is $342.35 \pm 29.59 \mathrm{mg} / \mathrm{dl}$ for control mice, and $334.72 \pm$ $22.37 \mathrm{mg} / \mathrm{dl}$ for SSW-exposed mice, respectively.

To determine if the changes in the lipid levels induced by SSW lead to an adverse effect in the hApoB100 transgenic mice (57BL/6Ntac-tgN) [25], Oil-Red-O staining of cross sections of the heart/aorta tissues were performed. SSWexposed animals did not only accumulate more lipids in the aortic walls (Figure 3A-D), but also had many of the smaller vessels in the heart tissue itself that were almost filled with lipid (Figure 3E, F). The lesion areas measured in the cross sections of the aorta account for $23.83 \pm$ $3.41 \%$ and $49.05 \pm 3.67 \%$ of the total aorta wall areas for control mice and SSW exposed mice, respectively (Figure $3 \mathrm{G})$. To confirm these results, transgenic mice expressing only human apoB100 were used. These latter mice more closely mimic human conditions because they produce human apoB100 that is a constituent of the atherogenic LDL, but not apoB48, a major cholesterol carrier in mice that is normally not considered to associate with atherogenic lipoproteins [26]. The same effects were found: more lipids accumulated in the aortic wall and in the small vessels of the heart after cigarette smoke exposure (data not shown).

The amount of total cholesterol and triglycerides in liver tissue were measured because synthesis and metabolism of lipids occur in the liver. Although there was no significant change in the total cholesterol level (Figure 4A), the triglyceride levels increased significantly after the mice were exposed to SSW (Figure 4B). Oil-Red-O staining of liver sections showed that there was much more lipid accumulation in the liver of mice exposed to SSW (Figure $4 \mathrm{D})$ than in the liver of control mice (Figure 4C). DiffQuick staining shows that the lipid droplets are much bigger in the SSW smoking mice than in the control mice (Figure 4E \&4F).

\section{Mice exposed to SSW have increased levels of MCP-I in both plasma and heart/aortic tissues}

MCP-1 has been shown to be a critical participant in atherogenesis because it is a potent chemoattactant for monocytes that infiltrate the intimal layer of arterial walls following injury $[1,2,4]$. Thus, the levels of MCP-1 in the plasma of SSW-exposed mice were examined and were found that early in the process of smoking the mice have normal MCP-1 levels but by the end of one year of smoking there is a significant increase in the levels of circulating MCP-1 (Figure 5A). The heart/aorta tissues were also
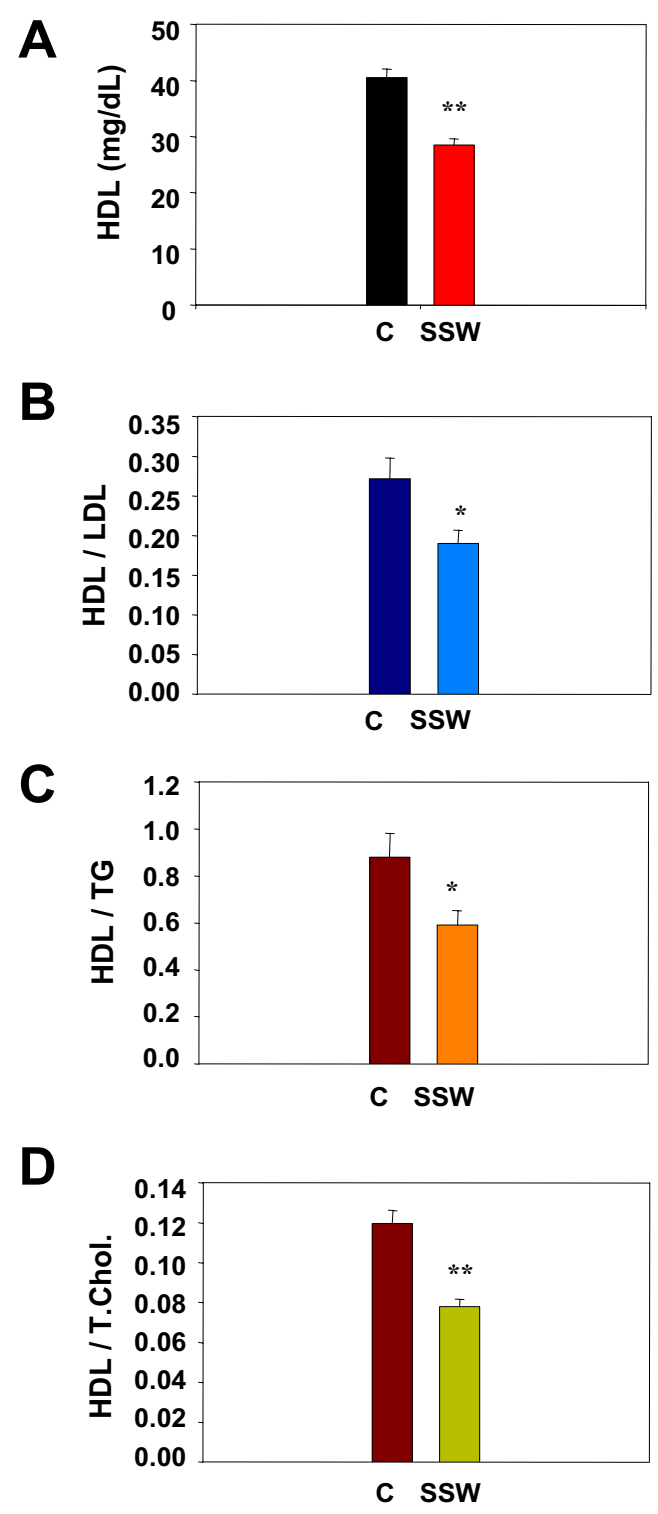

\section{Figure 2}

Effect of cigarette smoke on the HDL and its ratio to other plasma lipids. Mice were exposed to SSW $6 \mathrm{hrs} /$ day intermittently, 5 days a week. Blood samples were collected from the tail vein and, after centrifugation, the plasma was used to analyze for levels of HDL and other lipids by enzymatic reaction using colorimetric methods with commercially available kits (Wako Chemicals). After incubating with coloring reagent that only reacts with a specific cholesterol or type of lipid, the absorbance was measured and the concentration of each was calculated by plotting the measured values against a standard curve. (A) The levels of HDL in the blood of mice exposed to SSW are significantly lower than in the non-exposed mice. The ratios of HDL to LDL (B), HDL to TG (C), and HDL to TC (D) are all significantly lower in the SSW exposed mice. 
Control
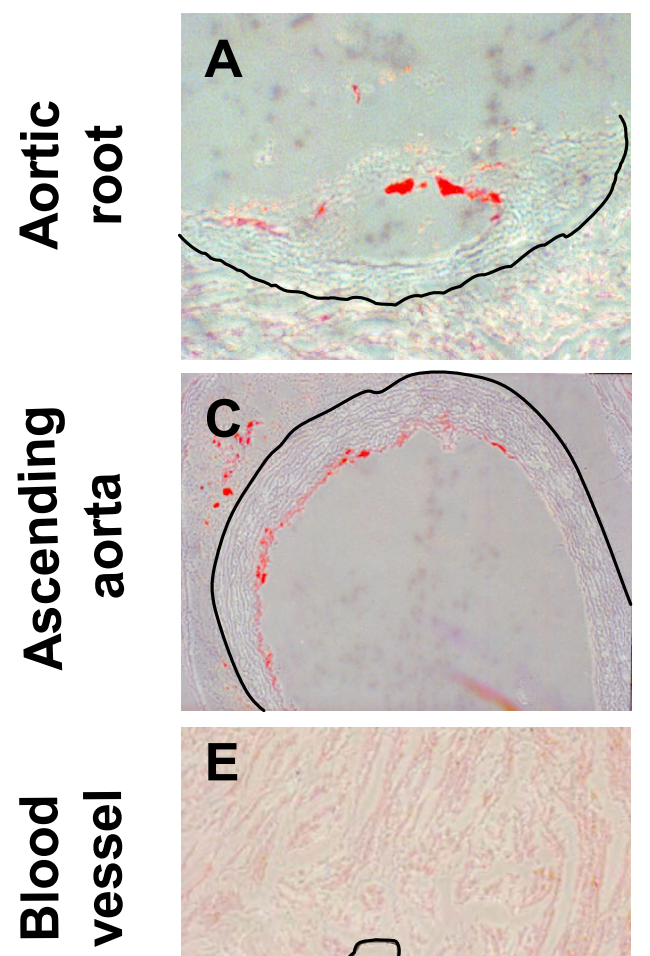

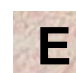

E

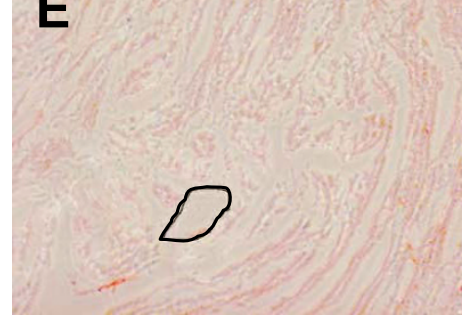

G
SSW
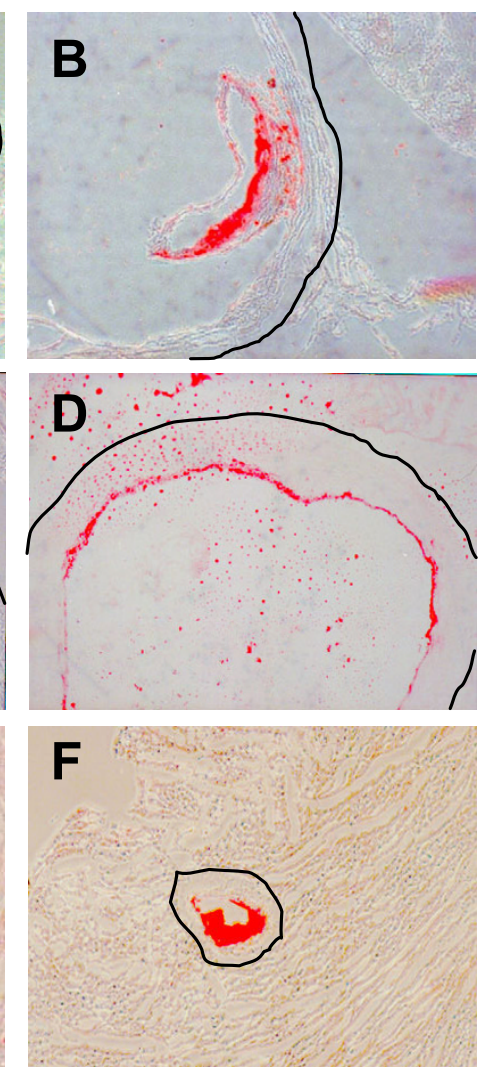

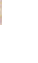
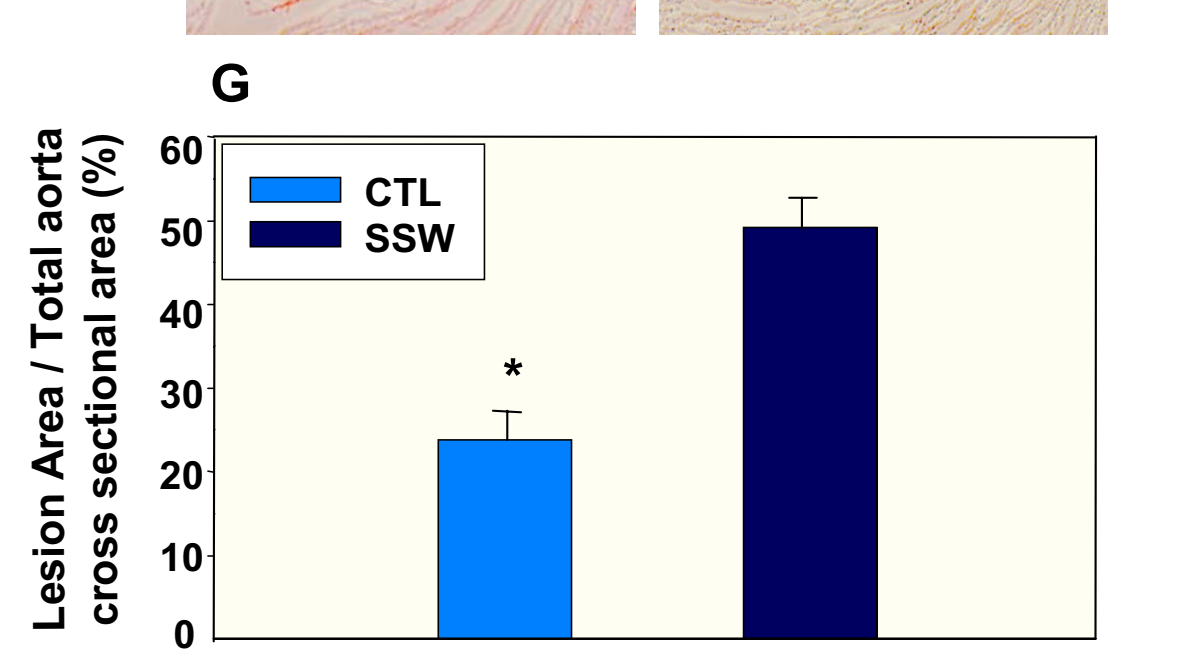

\section{Figure 3}

Lipid accumulation in arterial blood vessels. Oil red $O$ was used to detect the presence of lipids in tissue sections of the heart and aorta. (A) \& (B) Presence of higher lipid deposition in the root of the aorta in the smoke-exposed mice. (C) \& (D) Similar to A\&B but in the proximal part of ascending aorta. (E) \& (F) Small blood vessels in the heart muscle of SSW- exposed mice show much more lipid accumulation than in control mice. Thin black lines outline the outside of the vessel walls. (G) The lesion area in both control and SSW-exposed mice was measured as described in the Materials and Methods. The results are expressed as percentage of total area of aorta wall in cross section. Data are mean \pm SEM for each group. Statistical analyses were done according to unpaired $t$ test. $* \mathrm{P}<0.05 \mathrm{vs}$. control. The mice were exposed to SSW for I year. The images are representative of 2 mice per group. 


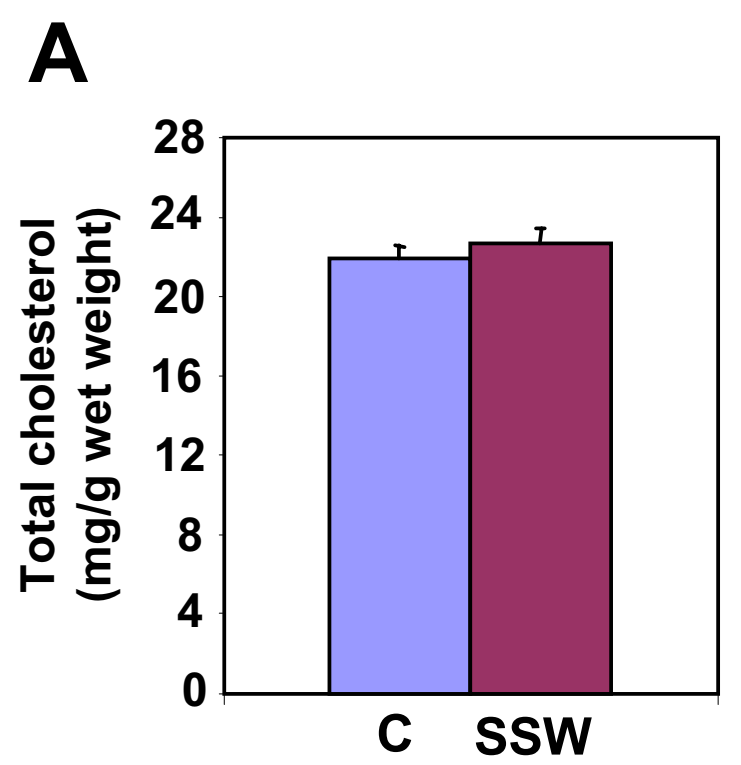

\section{B}
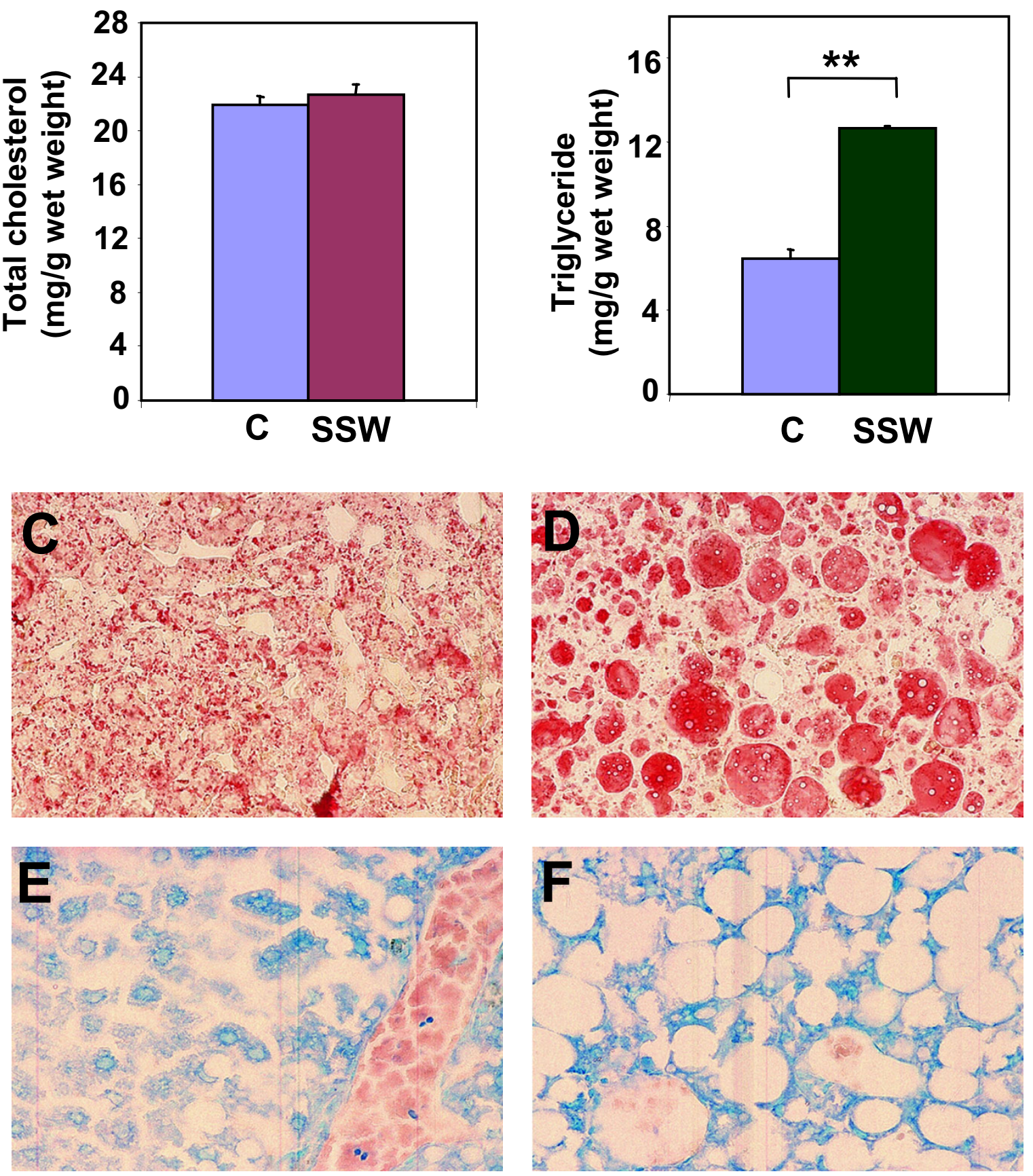

\section{Figure 4}

Lipid accumulation in liver tissue. About equal amounts of snap-frozen liver from the sacrificed mice of both control and SSW mice were used for lipid extraction with chloroform: methanol (2:I). The extracted lipids were dried and redissolved in 1\% Triton X-100. Commercial kits (WAKO Chemicals USA, Inc., Richmond, VA) were used for determination of (A) total cholesterol and (B) triglycerides. (C-F) Oil Red O staining of frozen liver sections reveals the lipid contents in the liver of control mice (C) and SSW mice (D). The liver of control mice (E) and SSW mice (F) were also stained with Diff-Quick to show their histological structure. The mice were exposed to SSW for I year. Representative images of one mouse out of three. 
A

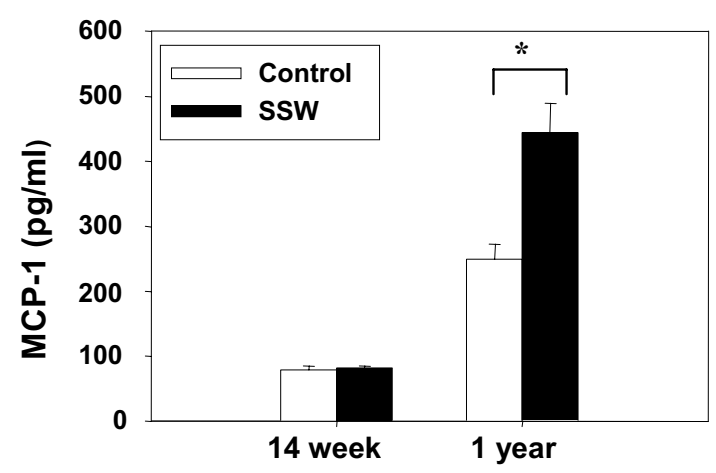

B

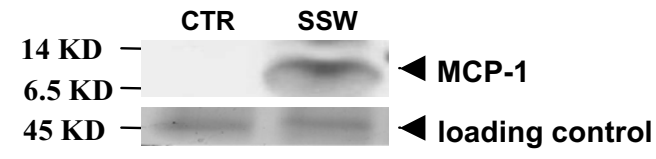

C
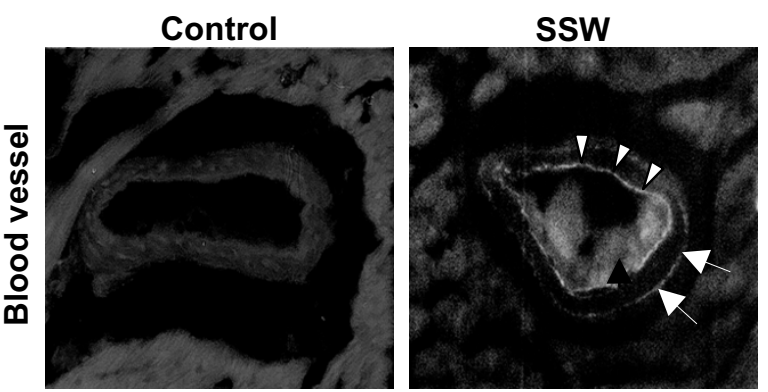

Figure 5

MCP-I in the plasma and heart/aortic tissues in human apoB 100 transgenic mice on high fat diet and exposed to SSW: (A) Levels of MCP-I in the plasma of smoking mice at two different time points during smoking. 30 $\mu \mathrm{l}$ of cytokine standard or plasma sample were added into the appropriate wells of a Mouse Cytokine array (Quansys Biosciences, Utah, USA) containing an antibody to this chemokine. The images were captured by a CCD camera and analyzed using the Quansys image analysis software. The concentration of MCP-I was calculated and plotted using a standard curve. (B) Immunoblot analysis for MCP-I in the heart/aortic tissue (the upper half of the heart together with ascending aorta). The protein extractions were quantified using a DC protein assay kit (Bio-Rad, Hercules, CA) and equal amounts of protein were loaded in each lane of SDSPolyacrylamide Gel. A 45 KD protein was used to evaluate equal loadings because this protein is always constant, independent of the treatment when the gels are stained with Commasie blue. (C): Immunolabeling for MCP-I in an arterial vessel of the heart tissue shows that this chemokine is produced by the endothelial cells (arrowheads) and by some of the cells in the adventitia (arrow). The mice were exposed to SSW periodically for I year. Representative images of one mouse out of three. examined for the level of MCP-1 protein by immunoblot analysis. These tissues were found to contain higher levels of the chemokine (Figure 5B); immunolabeling showed MCP-1 is primarily localized in the endothelial cells of large vessels (Figure 5C; arrowheads). Some staining was also present in cells of the adventitia (Figure 5C; arrows). These results in apoB100 mice were independent of apoB48 expression.

\section{Presence of macrophages in the arterial walls of SSW- exposed mice}

The process of atherogenesis is characterized by monocyte migration from the lumen to the intimal (subendothelial) layer of the blood vessel wall and there, in the presence of cytokines, differentiate into macrophages. These macrophages then take up oxidized LDL, which results in cholesteryl ester accumulation and "foam cell" formation, leading to early plaque formation. To determine the effect of SSW on these cell types in the heart blood vessels, tissue sections from the control and SSW exposed mice were immunolabeled with antibodies to F4/80, a marker for macrophages. Many more macrophages were present in the mice exposed to SSW smoke than in those breathing fresh air (Figure 6A, B). On the other hand, probing for neutrophils using antibodies to myeloperoxidase showed that these leukocytes are not present in the arterial vessel walls even in the mice exposed to SSW (Figure 6C, D), hence the effects of SSW are very specific for macrophages. These results support previous studies that showed that neutrophils were not implicated in atherosclerotic lesion development.

\section{Changes in adiponectin and TNF $\alpha$ levels in the plasma of SSW-exposed mice}

Adiponectin is a protein primarily secreted by adipocytes that has potential anti-atherogenic properties [39-41]. The possibility that SSW exposure results in a decrease in the levels of circulating adiponectin was examined. Using immunoblot analysis and reducing conditions, it was found that the mice exposed to SSW had decreased plasma levels of adiponectin monomer (Figure 7A).

Production of MCP-1 and adiponectin are stimulated by TNF $\alpha$ [42-44]. At 14 weeks of smoking, there were no significant changes in the TNF $\alpha$ levels caused by exposure to SSW smoke. However, after 1 year of smoking, plasma $\mathrm{TNF} \alpha$ levels were significantly increased compared to the control mice (Figure 7B).

\section{Changes in cytokine profiles in the plasma of SSW- exposed mice}

T-cell activation is an ongoing process in atherosclerotic lesions [45]. These immune cells can become activated and produce pro-inflammatory and cell-mediated responses (Th1 type), or produce cytokines that activate 

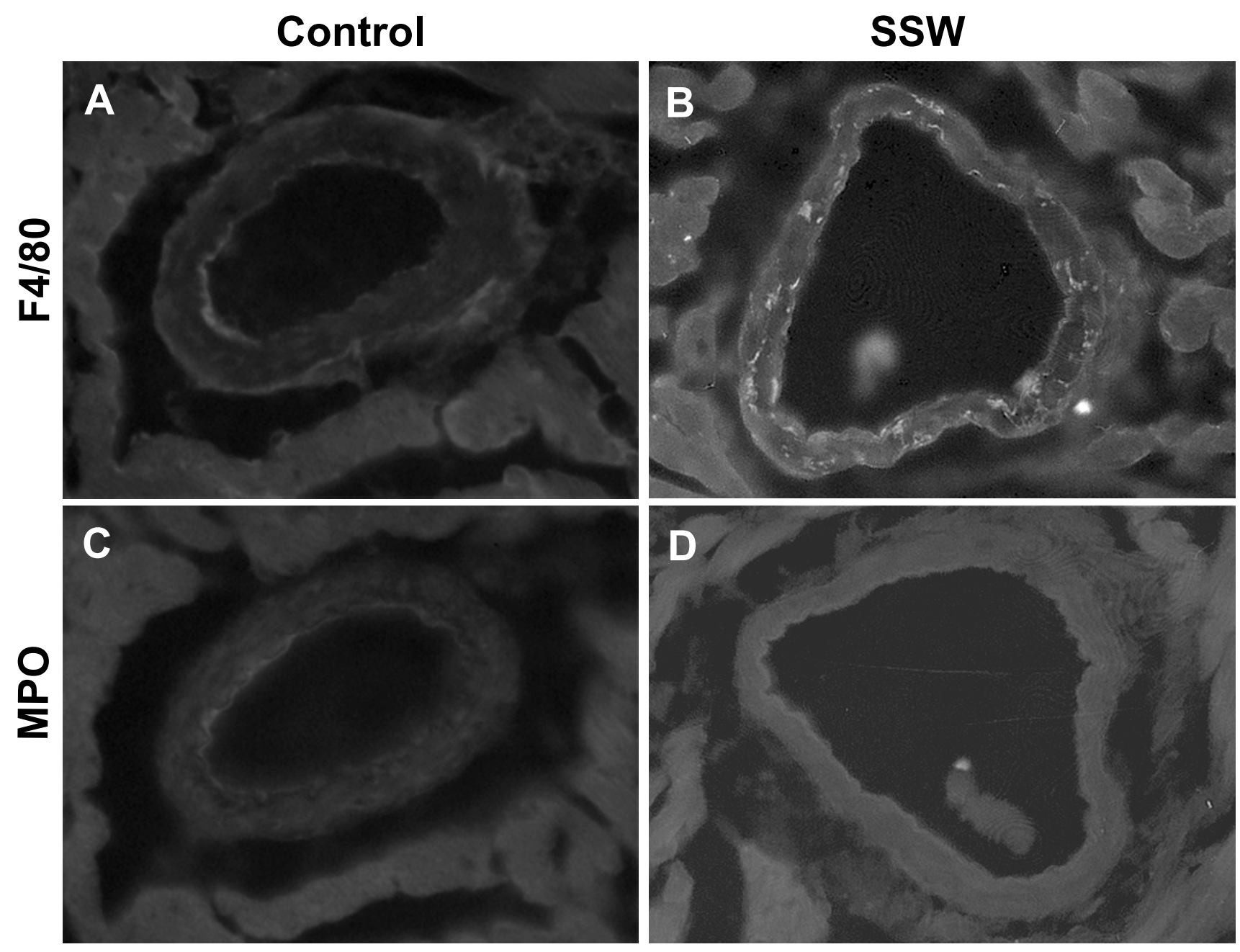

\section{Figure 6}

Macrophages and neutrophils in apoB 100 transgenic mice on high fat diet: (A) \& (B) Tissue sections of arterial blood vessels in the heart were immunolabeled with the antibody to F4/80 which is specific to macrophages, and (C) \& (D) with an antibody to myeloperoxidase to detect neutrophils. Macrophages were observed in the walls of arterial vessels in mice exposed to SSW smoke but not in the control mice. However, neutrophils were not found in the arterial vessel walls of either control mice or mice exposed to SSW. The mice were exposed to SSW for I year as described in the Materials and Methods. Representative images of one mouse out of three.

antibody-producing cells (Th2 type). Using a cytokine antibody array containing antibodies to detect Th1 and Th2 responses, we measured cytokine levels in the plasma of mice exposed to SSW. Cytokines such as IL-12 that promote Th1 responses and others such as IL- 4 that promote Th2 responses were detected. It was found that at 14 weeks of SSW smoking, the plasma levels of the proinflammatory Th1-inducing IL-12 cytokine was significantly increased (Figure 8A) whereas IL-4, that promotes Th2 responses and antibody production, was significantly lower in the mice exposed to SSW smoke (Figure 8B). However, at 1 year of exposure to SSW, whereas the levels of IL-12 decreased slightly (Figure 8A), the levels of IL-4 remained sharply decreased (Figure 8B). Another critical cytokine required for Th1 immunity, IFN $\gamma$, also significantly increased at 1 year of exposure to SSW (Figure 8C). To further explore the possibility that Th1 cytokines remain elevated in the blood of smokers, we immunolabeled sections of spleen with antibodies to CD4, IL-4, and IFN $\gamma \gamma$ and counted the number of cells that were positive for CD4, IL-4, and IFN $\gamma$. The results showed that the ratio of IFN $\gamma$ to IL-4 was 2.82:1 in mice exposed to SSW, compared to 1.20:1 in control mice (Fig 9 and table 1). These results taken together suggest that smokers are in a proinflammatory state. That is, the normal switch from Th1 to Th2 response during immune system activation upon 
A

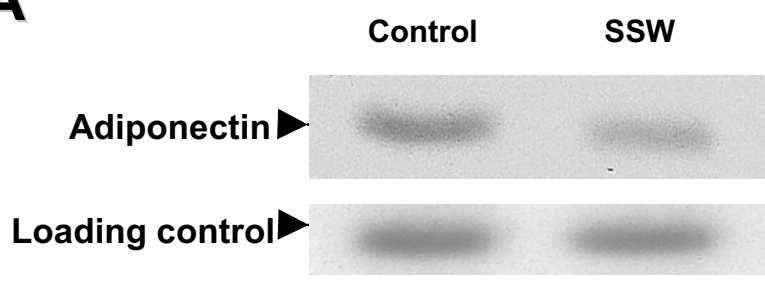

B

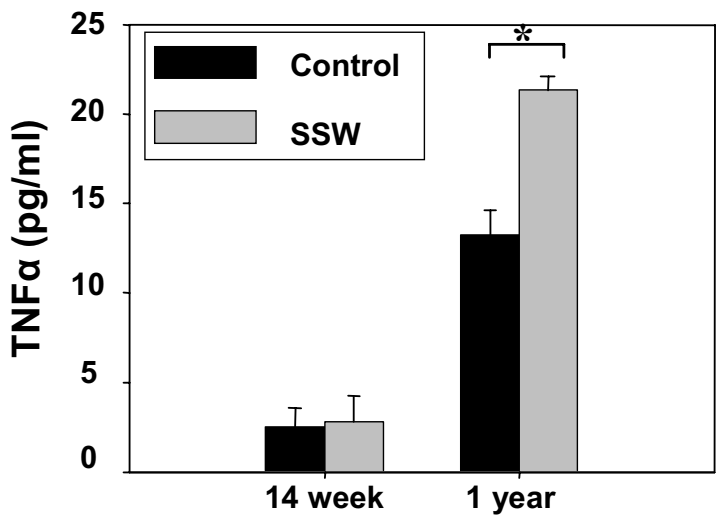

Figure 7

Plasma levels of adiponectin and TNF $\alpha$. (A) Immunoblot analysis shows the levels of adiponectin in the plasma. Blood sample from both control and SSW smoking mice were applied to $7.5 \%$ polyacrylamide electrophoresis gel and transferred to the nitrocellulose membrane. Adiponectin was probed with a goat anti-mouse adiponectin antibody and with a secondary conjugated to HRP for subsequent use with the enhanced chemiluminescence system (ECL, Amersham Pharmacia). Less adiponectin was detected in the plasma of mice exposed to SSW. Samples representative of 2 animals per group. (B) Cytokine array results showing TNF $\alpha$ levels in the plasma. At early stages of smoking, there was no significant difference between the TNF $\alpha$ levels in the control and SSW smoked mice, whereas at late stages of SSW smoking, the TNF $\alpha$ level in plasma was significantly increased. This increment was correlated with the decrease of adiponectin and increment of MCP-I in the plasma. Samples were done in triplicate.

an insult, in this case circulating cigarette smoke components, does not occur.

\section{Discussion}

It is well known that cigarette smoking is detrimental to human health, leading to cardiovascular disease and cancer. Although cigarette smoke is widely accepted as an environmental factor that aggravates atherosclerosis [1,10-12], less well known are the biological processes by which cigarette smoke stimulates atherogenesis. By using a smoking system that greatly decreases the stress exerted
A

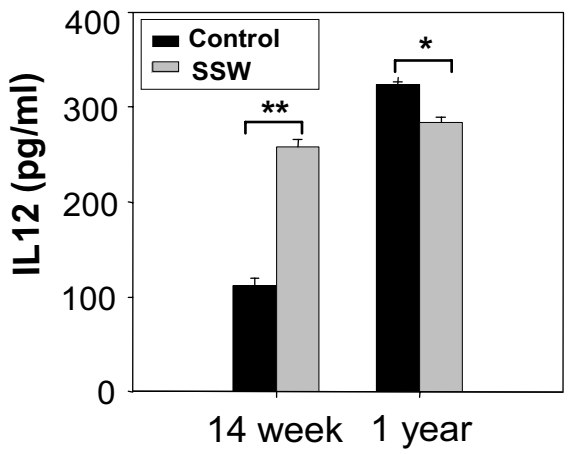

B

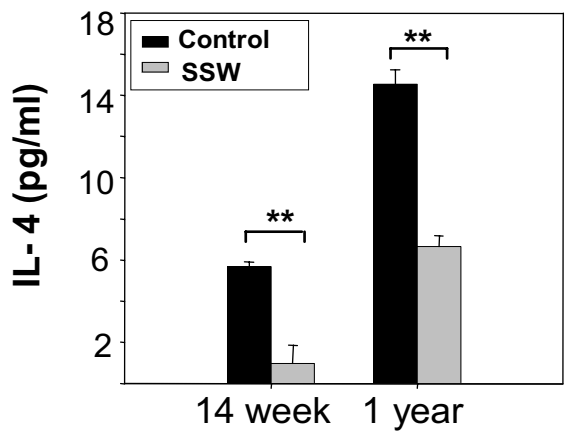

C

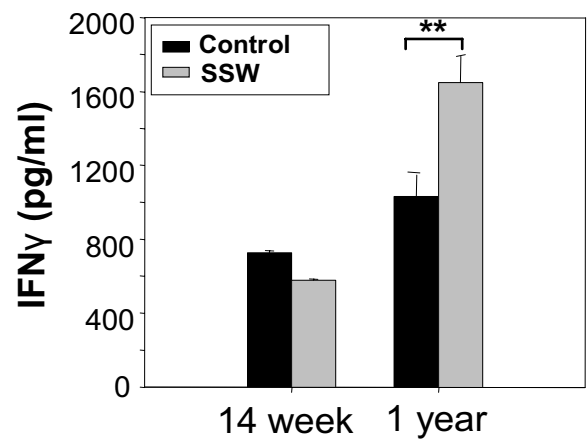

Figure 8

Plasma levels of specific cytokines related to the immune response in atherosclerosis. Cytokine array results show the changes of the cytokines IL-I2 (A), IL-4 (B), and IFN $\gamma(\mathbf{C})$ in the plasma of $\mathrm{hApoBI} 00$ transgenic mice that were exposed to SSW smoke. The cytokines in the plasma were captured by antibodies coated on the bottom of 96well plates (Quansys Biosciences, Utah, USA). After washing, probing with streptavidin-HRP, and reacting with substrate, the images were captured with CCD camera (Roper Micro$\max$ (300B). The strength of signal was translated into concentration of cytokine by plotting against a standard curve. 

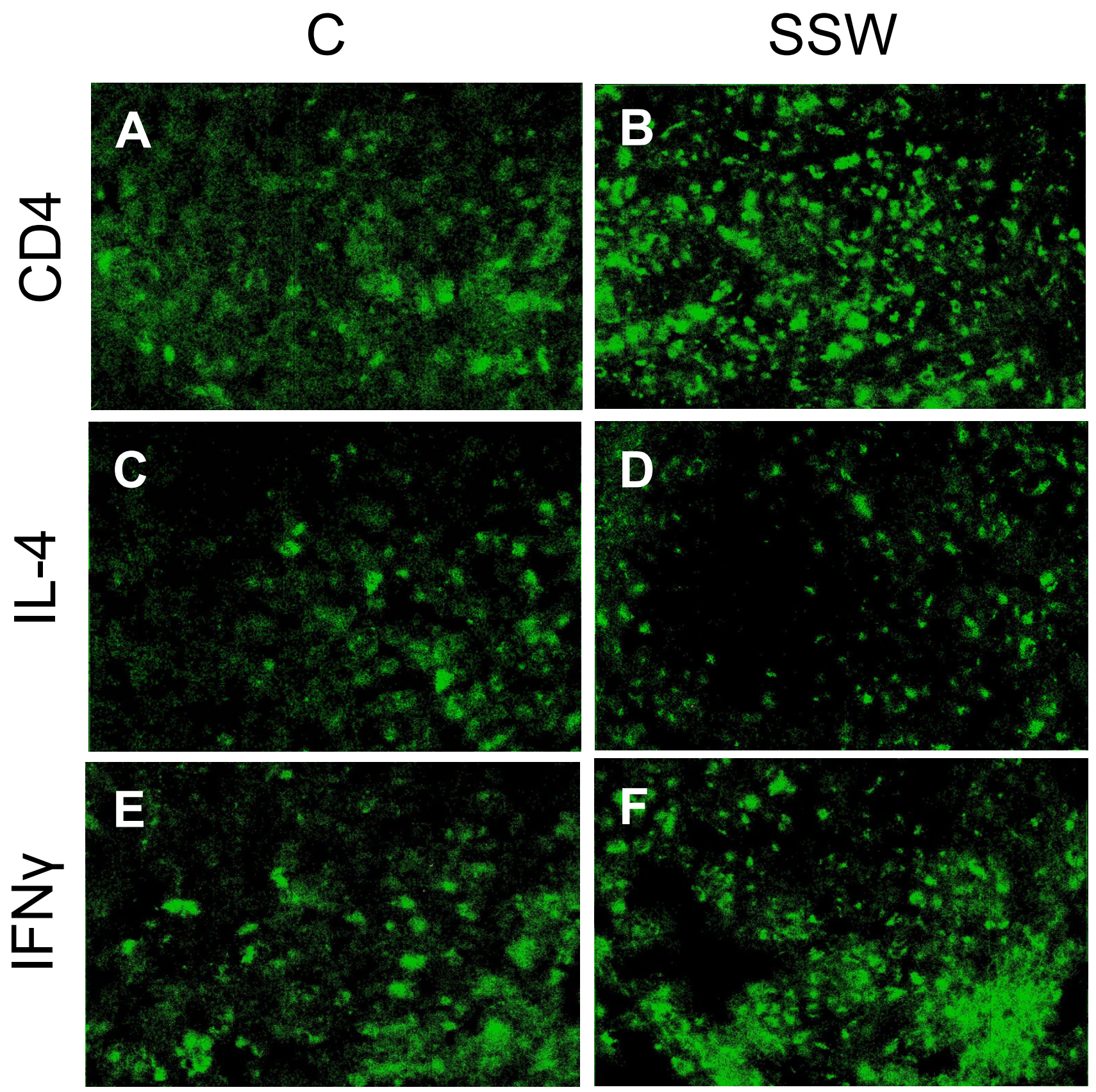

Figure 9

SSW smoke exposure favors a Th I immune response in human apoB I 00 Transgenic mice. Tissue sections of the spleen were labeled with rat anti-mouse CD4+, IL-4, and IFN $\gamma$ antibodies, and detected by FITC-labeled goat anti-rat IgG. (AF) Immunolabeling showing the peripheral lymphocytes in spleen expressing CD4+ (A, B), IL-4 (C, D), and IFN $\gamma(\mathbf{E}, \mathbf{F})$ in hApoBI00 transgenic mice that were exposed to normal air $(\mathbf{A}, \mathbf{C}, \mathbf{E})$ or SSW smoke $(\mathbf{B}, \mathbf{D}, \mathbf{F})$.

on the animals, the effects of SSW smoke can be more accurately decoupled from effects of stress. Here we have shown that: (i) SSW smoke decreases circulating HDL and alters the physiology of other lipids, resulting in a significant increase in the area of the lesions found in the aorta and in more lipid deposition in the blood vessels of the heart; (ii) mice exposed to SSW have increased levels of MCP-1; (iii) macrophages accumulate in the arterial walls of mice exposed to cigarette smoke; (iv) adiponectin levels are decreased in the plasma of SSW smoking mice; (v) 
Table I: Number of splenic cells/HPF that express CD4+, IL-4 and IFN $\gamma$

\begin{tabular}{|c|c|c|c|c|}
\hline \multirow[b]{2}{*}{ Treatment } & \multicolumn{3}{|c|}{ Cell number ${ }^{a}$} & \multirow[b]{2}{*}{ IFN $\gamma /$ IL- 4} \\
\hline & CD4+ & IL-4 & IFN $\gamma$ & \\
\hline Control & $\begin{array}{c}20.67 \pm 4.49 \\
(n=3)^{*}\end{array}$ & $\begin{array}{c}27.00 \pm 2.31 \\
(n=3)^{* *}\end{array}$ & $\begin{array}{c}32.23 \pm 2.33 \\
(n=3)\end{array}$ & 1.20 \\
\hline SSW & $\begin{array}{c}112.00 \pm 4.62 \\
(\mathrm{n}=3)^{\$, \#, .,}\end{array}$ & $\begin{array}{c}33.33 \pm 6.69 \\
(n=3)^{\S . \dagger}\end{array}$ & $\begin{array}{c}94.00 \pm 7.81 \\
(n=3)^{\ddagger}\end{array}$ & 2.82 \\
\hline
\end{tabular}

cigarette smoke stimulates accumulation of lipids in liver cells; and (vi) SSW stimulates cytokines that enhance the Th1 response (e.g. IL-12 and IFN $\gamma$ ) and suppresses cytokines that stimulate the Th2 response (e.g.IL-4).

Most humans suffering from atherosclerosis only have a moderately elevated cholesterol level, and have normal $\mathrm{LDL}$ receptors; hence the apoB 100 transgenic mice used in this study may be a more physiologically relevant model for the study of atherosclerosis in most humans than other genetically modified mice. ApoB100 mice develop atherogenesis only on a relatively high fat diet, have moderately elevated cholesterol levels and have elevated levels of the apoB100 protein in their blood [22]. In general, humans that develop atherosclerosis have all three conditions; in particular they have elevated apoB100 [46-48] and consume high fat foods. All these features make human apoB100 transgenic mice the murine model of choice to study the "common" atherosclerotic disease state in humans exposed to cigarette smoke. As shown here, cigarette smoke increases lipid accumulation in blood vessels and induces more macrophage accumulation in the subendothelial layers of the aorta. These results correlate well with previous reports in which hyperlipidemic children were found to have low serum HDL levels when exposed to second-hand smoke [49]. The accumulation of macrophages in blood vessel walls and the presence of lipids are key steps in atherosclerotic plaque initiation.

Because MCP-1 functions in attracting monocytes, which migrate through the endothelial layer, differentiate into macrophages in the arterial walls and become activated and ingest oxidized lipids, it is quite possible that this molecule is a key modulator in the process of initiation of atherosclerosis plaque formation. For example, MCP-1 production is stimulated by balloon injury in rabbits [19] and pigs [20] and this stimulation is correlated with an increase in the number of monocytes and macrophages in the arterial wall. Furthermore, studies in apoE-/- mice show that these mice over-express MCP-1 and have accelerated atherosclerosis [21]. In contrast, knockout of either MCP-1 [22] or the MCP-1 receptor, CCR2, resulted in a marked reduction in atherosclerotic plaque formation [23]. Our data show that in mice exposed to SSW, the endothelial layer of arterial blood vessels produces higher levels of MCP-1, showing that this chemokine is in the right place at the right time to contribute to the initiation of plaque formation. Studies are under way to determine whether the MCP-1 increase is required for SSW-induced atherogenesis.

Artherosclerotic plaque formation may also be related to adipose tissue secreted molecules such as adiponectin. This is a 247 amino acid bioactive protein secreted by adipocytes [39]. Although adiponectin is an important modulator of glucose and lipid metabolism, recent studies found that adiponectin is potentially anti-atherogenic and anti-inflammatory $[40,41]$. In apo-E -/- mice, atherosclerotic plaque size decreased when adiponectin was overexpressed $[50,51]$. In patients with cardiovascular disease, plasma concentrations of adiponectin decreased in smokers $[52,53]$. Our data suggests that adiponectin is another modulator of cigarette-smoke-induced plaque formation. The low concentration of adiponectin in the blood of SSW-exposed mice shows that cigarette smoke can affect the levels of this protein in circulation. We are in the process of obtaining transgenic mice expressing both apoB100 and adiponectin to determine whether excess of this latter protein can decrease cigarette-smoke-induced atherogenesis.

MCP-1 is expressed by many different cell types upon stimulation of the cells by stress-inducing agents whereas adiponectin is constitutively expressed by adipocytes and is found at high concentrations $(2-10 \mu \mathrm{g} / \mathrm{ml})$ in the blood. Is the inverse expression level of MCP-1 and adiponectin important in SSW-induced atherosclerotic 
plaque formation? This connection may be critical for plaque formation and could be dependent on the cellmediated immune responses to cigarette smoke components. As an important inflammatory cytokine, TNF $\alpha$ can upregulate MCP-1 expression [53] and down-regulate adiponectin expression [44]. In SSW-exposed mice, the MCP1 levels at 14 weeks of smoking correlate well with the levels of TNF $\alpha$ at this same time. Furthermore, after 1 year of SSW exposure, when the levels of TNF $\alpha$ are significantly increased, the MCP-1 levels are also significantly increased whereas adiponectin levels are significantly decreased. Therefore, on the one hand, cigarette smoke increased the levels of TNFa thereby causing MCP-1 expression by the endothelial cells of the aorta to attract monocytes, which led to accumulation of oxidized lipids in the subendothelial layer. However, on the other hand, increased levels of TNFa induced by cigarette smoke also decreased the circulating levels of adiponectin, which limited its function in protecting the endothelial layer. These two processes thus may both contribute to enhancing the progression of the initiation of atherosclerotic plaque formation.

T-cells are known to be present in atherosclerotic lesions, suggesting that they are important in cell-mediated immune responses during atherogenesis. Most of these $\mathrm{T}$ cells are CD $4^{+} \mathrm{T}$ cells (Th type). The pro-inflammatory cytokine IL-12, the center for Th1 immunity [54], stimulates Th1 cell differentiation and expression of other cytokines, such as TNF $\alpha$ and IFN $\gamma$ [55]. IL-12 levels were significantly increased at the early stage of SSW exposure, and this correlated well with the significant increase in the levels of TNF $\alpha$ over time. There was no significant change in the level of IL-12 for the mice exposed to SSW, meaning that these mice are constantly stimulated to produce this cytokine by SSW components. These data show that SSW can stimulate IL-12 and IFN $\gamma$ expression and thus enhance the Th1 response in atherogenic lesion formation. On the other hand, SSW also suppress the expression IL-4, a Th2 stimulating cytokine indicating that the switch from a pro-inflammatory Th1 response to an antibody-dependent Th2 response is impaired.

In addition to all of these effects, cigarette smoke also causes hepatic steatosis (fatty liver), which in clinical studies correlates with atherogenesis. Although there are no direct studies regarding the relationship between cigarette smoking and hepatic steatosis, it has been reported that cigarette smoking can increase severity of hepatic lesions in patients with chronic hepatitis C $[56,57]$. Starting smoking was also associated with deterioration of serum alanine aminotransferase (ALT) in NAFLD patients [58]. One potential complication in interpreting our results on cigarette smoke-induced steatosis is that apoB100 transgenic mice require high fat diet to induce lesion develop- ment in the aorta in a reasonable time frame. The high fat diet contains cholate, which is known to cause liver dysfunction and inflammation. However, we believe that our results show true effects of cigarette smoke because, although the control groups were not exposed to SSW, they were fed the same diet as the mice that were exposed to SSW. Therefore, the difference in lipid metabolism can be attributed to the effect of cigarette smoke. However, the possibility remains that some of the effects are due to an interaction between smoke exposure and dietary cholate.

\section{Conclusion}

Our results suggest that the levels of both MCP-1 and adiponectin are regulated by the cytokine $\mathrm{TNF} \alpha$, which is modulated by IL-12. Because modulation of both MCP-1 and adiponectin plays important functions in atherosclerosis, the imbalance of these two molecules may be key to atherogenesis. Our results also suggest that SSW inhibits the switch of Th1 to Th2 response, leading to an imbalance of the Th response, thereby linking the importance of the immune response to the process of second-hand smoke-induced atherogenesis and suggesting that smokers may live in a permanent state of inflammation.

\author{
Abbreviations \\ ApoB Apolipoprotein B \\ MSW MainStream Whole \\ SSW SideStream Whole \\ MCP-1 monocyte chemoattractant protein-1 \\ LDL low density lipopotein \\ ApoE apoliprotiein E
}

LDLR low density lipopotein receptor

TPM total particulate matter

TG triglyceride

TC total cholesterol

IL interleukin

TNF $\alpha$ tumor necrosis factor alpha

VCAM vascular adhesion molecules

ICAM intercellular adhesion molecules 


\section{Competing interests}

Part of the funding to carry out the studies presented in this manuscript came from the Philip Morris External Research Program.

\section{Authors' contributions}

HY carried out all studies except for carboxyhemoglobin measurement. LW conceived the smoking system and animal model selection and participated in system calibration and cholesterol measurement. $\mathrm{MB}$ and $\mathrm{MZ}$ carried out carboxyhemoglobin measurement. CM helped to smoke the mice and to process the tissues. MS and REP supplied the human apoB 100 transgenic mice of $50 \%$ C57 black/50\% SJL background. MMG conceived and designed the studies with HY and LW, and contributed to manuscript preparation and writing. YM did the cytokine array experiment. All authors read and approved the final manuscript.

\section{Acknowledgements}

We would like to thank Dr. David Carter for helping with acquisition of the images of the cytokine array and Dr. H. Green for proofreading the manuscript. Part of this work was performed in the Center for Plant Cell Biology at UC Riverside. Funding came from the UC Tobacco Related Disease Research Program and Philip Morris External Research Program to MMG, and National Heart, Lung and Blood Institute to REP.

\section{References}

I. Glass CK, Witztum JL: Atherosclerosis. the road ahead. Cell 200I, 104:503-5I6.

2. Ross R: The pathogenesis of atherosclerosis: a perspective for the 1990s. Nature 1993, 362:801-809.

3. Bruce I, McNally J, Bell A: Enhanced monocyte generation of reactive oxygen species in primary systemic vasculitis. I Rheumatol 1997, 24:2364-2370.

4. Terkeltaub R, Boisvert WA, Curtiss LK: Chemokines and atherosclerosis. Curr Opin Lipidol 1998, 9:397-405.

5. Cybulsky MI, Gimbrone MA Jr.: Endothelial expression of a mononuclear leukocyte adhesion molecule during atherogenesis. Science 1991, 25 I:788-79|.

6. Collins RG, Velji R, Guevara NV, Hicks MJ, Chan L, Beaudet AL: P Selectin or intercellular adhesion molecule (ICAM)-I deficiency substantially protects against atherosclerosis in apolipoprotein E-deficient mice. J Exp Med 2000, 191:189-194.

7. Dong ZM, Chapman SM, Brown AA, Frenette PS, Hynes RO, Wagner DD: The combined role of $P$ - and E-selectins in atherosclerosis. J Clin Invest 1998, I 02: 145-152.

8. Wang N, Tabas I, Winchester R, Ravalli S, Rabbani LE, Tall A: Interleukin 8 is induced by cholesterol loading of macrophages and expressed by macrophage foam cells in human atheroma. J Biol Chem 1996, 27 I:8837-8842.

9. Lusis AJ: Atherosclerosis. Nature 2000, 407:233-24I.

10. Wilson PW, D'Agostino RB, Levy D, Belanger AM, Silbershatz $H$, Kannel WB: Prediction of coronary heart disease using risk factor categories. Circulation 1998, 97: 1837-1847.

II. Grundy SM, Balady G], Criqui MH, Fletcher G, Greenland P, Hiratzka LF, Houston-Miller N, Kris-Etherton P, Krumholz HM, LaRosa J, Ockene IS, Pearson TA, Reed J, Washington R, Smith SC Jr.: Primary prevention of coronary heart disease: guidance from Framingham: a statement for healthcare professionals from the AHA Task Force on Risk Reduction. American Heart Association. Circulation 1998, 97:|876-1887.

12. Grundy SM, Pasternak R, Greenland P, Smith S Jr., Fuster V: Assessment of cardiovascular risk by use of multiple-risk-factor assessment equations: a statement for healthcare professionals from the American Heart Association and the American College of Cardiology. Circulation 1999, 100:|48|-|492.
13. Smith C], Fischer TH: Particulate and vapor phase constituents of cigarette mainstream smoke and risk of myocardial infarction. Atherosclerosis 200I, I 58:257-267.

14. Howard G, Wagenknecht LE, Cai J, Cooper L, Kraut MA, Toole JF: Cigarette smoking and other risk factors for silent cerebral infarction in the general population. Stroke 1998, 29:913-917.

15. Green HM, Li QJ, Martins-Green M: The Effects of Cigarette Smoke on Activation of Chemokines [abstract]. Mol Biol of the Cell 1999, I0(Suppl):2463.

16. Wong LS, Green HM, Martins-Green M: Cigarette SmokeInduced Changes in the Structure and Function of Fibroblasts [abstract]. Mol Biol of the Cell 1999, 10 (Suppl): 1719.

17. Wong LS, Martins-Green M: Differential effects of active and passive cigarette smoke on febroblasts, cells that are critical for proper healing [abstract]. Mol Biol of the Cell 200I, I 2(Suppl): 1213

18. Horuk R: Chemoattractant Ligands and Their Receptors. In Pharmacology and Toxicology: Basic and Clinical Aspects Edited by: Hollinger MA. N.Y, CRC Press; 1996:377.

19. Taubman MB, Rollins BJ, Poon M, Marmur J, Green RS, Berk BC, Nadal-Ginard B: JE mRNA accumulates rapidly in aortic injury and in platelet-derived growth factor-stimulated vascular smooth muscle cells. Circ Res 1992, 70:3|4-325.

20. Wysocki SJ, Zheng MH, Smith A, Lamawansa MD, lacopetta BJ, Robertson TA, Papadimitriou JM, House AK, Norman PE: Monocyte chemoattractant protein-I gene expression in injured pig artery coincides with early appearance of infiltrating monocyte/macrophages. J Cell Biochem 1996, 62:303-3I3.

21. Aiello RJ, Bourassa PA, Lindsey S, Weng W, Natoli E, Rollins BJ, Milos PM: Monocyte chemoattractant protein-I accelerates atherosclerosis in apolipoprotein E-deficient mice. Arterioscler Thromb Vasc Biol 1999, 19:1518-1525.

22. Gosling J, Slaymaker S, Gu L, Tseng S, Zlot CH, Young SG, Rollins BJ, Charo IF: MCP-I deficiency reduces susceptibility to atherosclerosis in mice that overexpress human apolipoprotein B. J Clin Invest 1999, 103:773-778.

23. Boring L, Gosling J, Cleary M, Charo IF: Decreased lesion formation in CCR2-/- mice reveals a role for chemokines in the initiation of atherosclerosis. Nature 1998, 394:894-897.

24. Griffith RB, Standafer S: Simultaneous mainstream-sidestream smoke exposure systems II. The rat exposure system. Toxicology 1985, 35:13-24.

25. Linton MF, Farese RV Jr., Chiesa G, Grass DS, Chin P, Hammer RE, Hobbs $\mathrm{HH}$, Young SG: Transgenic mice expressing high plasma concentrations of human apolipoprotein B 100 and lipoprotein(a). J Clin Invest 1993, 92:3029-3037.

26. Boren J, Lee I, Zhu W, Arnold K, Taylor S, Innerarity TL: Identification of the low density lipoprotein receptor-binding site in apolipoprotein B 100 and the modulation of its binding activity by the carboxyl terminus in familial defective apo-B 100 . Clin Invest 1998, 101:1084-1093.

27. Nishina PM, Verstuyft J, Paigen B: Synthetic low and high fat diets for the study of atherosclerosis in the mouse. J Lipid Res 1990, 31:859-869.

28. Purcell-Huynh DA, Farese RV Jr., Johnson DF, Flynn LM, Pierotti V, Newland DL, Linton MF, Sanan DA, Young SG: Transgenic mice expressing high levels of human apolipoprotein B develop severe atherosclerotic lesions in response to a high-fat diet. J Clin Invest 1995, 95:2246-2257.

29. Mayes RW: ACP Broadsheet No 142: November 1993. Measurement of carbon monoxide and cyanide in blood. J Clin Pathol 1993, 46:982-988.

30. Rodkey FL, Hill TA, Pitts LL, Robertson RF: Spectrophotometric measurement of carboxyhemoglobin and methemoglobin in blood. Clin Chem 1979, 25: 1388-1393.

31. Folch J, Lees M, Sloane Stanley GH: A simple method for the isolation and purification of total lipides from animal tissues. Biol Chem 1957, 226:497-509.

32. Carr TP, Andresen CJ, Rudel LL: Enzymatic determination of triglyceride, free cholesterol, and total cholesterol in tissue lipid extracts. Clin Biochem 1993, 26:39-42.

33. Wong LS, Green HM, Feugate JE, Yadav M, Nothnagel EA, MartinsGreen M: Effects of "second-hand" smoke on structure and function of fibroblasts, cells that are critical for tissue repair and remodeling. BMC Cell Biol 2004, 5: 13 . 
34. Gairola CG, Drawdy ML, Block AE, Daugherty A: Sidestream cigarette smoke accelerates atherogenesis in apolipoprotein EI- mice. Atherosclerosis 200I, I 56:49-55.

35. Mullick AE, McDonald JM, Melkonian G, Talbot P, Pinkerton KE, Rutledge JC: Reactive carbonyls from tobacco smoke increase arterial endothelial layer injury. Am J Physiol Heart Circ Physiol 2002, 283:H59l-7.

36. Nazaroff WW, Singer BC: Inhalation of hazardous air pollutants from environmental tobacco smoke in US residences. J Expo Anal Environ Epidemiol 2004, I4 Suppl I:S7I-7.

37. Scherer G: Carboxyhemoglobin and thiocyanate as biomarkers of exposure to carbon monoxide and hydrogen cyanide in tobacco smoke. Exp Toxicol Pathol 2006, 58:101-124.

38. Koul A, Singh A, Sandhir R: Effect of alpha-tocopherol on the cardiac antioxidant defense system and atherogenic lipids in cigarette smoke-inhaling mice. Inhal Toxicol 2003, I 5:5 I 3-522.

39. Maeda K, Okubo K, Shimomura I, Funahashi T, Matsuzawa Y, Matsubara $\mathrm{K}$ : cDNA cloning and expression of a novel adipose specific collagen-like factor, apMI (AdiPose Most abundant Gene transcript I). Biochem Biophys Res Commun 1996, 22I:286-289.

40. Ouchi N, Kihara S, Arita Y, Maeda K, Kuriyama H, Okamoto Y, Hotta K, Nishida M, Takahashi M, Nakamura T, Yamashita S, Funahashi T, Matsuzawa Y: Novel modulator for endothelial adhesion molecules: adipocyte-derived plasma protein adiponectin. Circulation 1999, 100:2473-2476.

4I. Ouchi N, Kihara S, Arita Y, Nishida M, Matsuyama A, Okamoto Y, Ishigami M, Kuriyama $\mathrm{H}$, Kishida K, Nishizawa $H$, Hotta K, Muraguchi M, Ohmoto Y, Yamashita S, Funahashi T, Matsuzawa Y: Adipocytederived plasma protein, adiponectin, suppresses lipid accumulation and class $A$ scavenger receptor expression in human monocyte-derived macrophages. Circulation 2001, 103:1057-1063.

42. Zhao B, Stavchansky SA, Bowden RA, Bowman PD: Effect of interleukin-Ibeta and tumor necrosis factor-alpha on gene expression in human endothelial cells. Am J Physiol Cell Physiol 2003, 284:CI577-83.

43. Parry GC, Martin T, Felts KA, Cobb RR: IL- I beta-induced monocyte chemoattractant protein-I gene expression in endothelial cells is blocked by proteasome inhibitors. Arterioscler Thromb Vasc Biol 1998, 1 8:934-940.

44. Bruun JM, Lihn AS, Verdich C, Pedersen SB, Toubro S, Astrup A, Richelsen B: Regulation of adiponectin by adipose tissue-derived cytokines: in vivo and in vitro investigations in humans. $\mathrm{Am}$ Physiol Endocrinol Metab 2003, 285:E527-33.

45. Hansson GK: Cell-mediated immunity in atherosclerosis. Curr Opin Lipidol 1997, 8:30I-3II.

46. Sniderman A, Shapiro S, Marpole D, Skinner B, Teng B, Kwiterovich $\mathrm{PO}$ Jr.: Association of coronary atherosclerosis with hyperapobetalipoproteinemia [increased protein but normal cholesterol levels in human plasma low density (beta) lipoproteins]. Proc Natl Acad Sci U S A 1980, 77:604-608.

47. Teng B, Sniderman AD, Soutar AK, Thompson GR: Metabolic basis of hyperapobetalipoproteinemia. Turnover of apolipoprotein B in low density lipoprotein and its precursors and subfractions compared with normal and familia hypercholesterolemia. J Clin Invest 1986, 77:663-672.

48. Sniderman A, Brown BG, Stewart BF, Cianflone K: From familial combined hyperlipidemia to hyperapoB: unravelling the overproduction of hepatic apolipoprotein B. Curr Opin Lipidol 1992, 3:137-142.

49. Neufeld EJ, Mietus-Snyder M, Beiser AS, Baker AL, Newburger JW: Passive cigarette smoking and reduced HDL cholesterol levels in children with high-risk lipid profiles. Circulation 1997, 96: I403-I407.

50. Yamauchi T, Kamon J, Waki H, Imai Y, Shimozawa N, Hioki K, Uchida S, Ito Y, Takakuwa K, Matsui J, Takata M, Eto K, Terauchi Y, Komeda K, Tsunoda M, Murakami K, Ohnishi Y, Naitoh T, Yamamura K, Ueyama Y, Froguel P, Kimura S, Nagai R, Kadowaki T: Globular adiponectin protected ob/ob mice from diabetes and ApoEdeficient mice from atherosclerosis. J Biol Chem 2003, 278:246I-2468.

5I. Okamoto Y, Kihara S, Ouchi N, Nishida M, Arita Y, Kumada M, Ohashi K, Sakai N, Shimomura I, Kobayashi H, Terasaka N, Inaba T, Funahashi T, Matsuzawa Y: Adiponectin reduces atherosclerosis in apolipoprotein E-deficient mice. Circulation 2002 106:2767-2770.

52. Miyazaki T, Shimada K, Mokuno H, Daida H: Adipocyte derived plasma protein, adiponectin, is associated with smoking status in patients with coronary artery disease. Heart 2003, 89:663.

53. Isoda K, Shiigai M, Ishigami N, Matsuki T, Horai R, Nishikawa K, Kusuhara M, Nishida Y, Iwakura Y, Ohsuzu F: Deficiency of interleukinI receptor antagonist promotes neointimal formation after injury. Circulation 2003, 108:516-518.

54. Trinchieri G, Wysocka M, D'Andrea A, Rengaraju M, Aste-Amezaga M, Kubin M, Valiante NM, Chehimi ]: Natural killer cell stimulatory factor (NKSF) or interleukin-I 2 is a key regulator of immune response and inflammation. Prog Growth Factor Res 1992, 4:355-368.

55. Uyemura K, Demer LL, Castle SC, Jullien D, Berliner JA, Gately MK, Warrier RR, Pham N, Fogelman AM, Modlin RL: Cross-regulatory roles of interleukin (IL)- I 2 and IL- I 0 in atherosclerosis. J Clin Invest 1996, 97:2130-2138

56. Mori M, Hara M, Wada I, Hara T, Yamamoto K, Honda M, Naramoto J: Prospective study of hepatitis $B$ and $C$ viral infections, cigarette smoking, alcohol consumption, and other factors associated with hepatocellular carcinoma risk in Japan. Am J Epidemiol 2000, I 5 I: |3 |- I39.

57. Pessione F, Ramond MJ, Njapoum C, Duchatelle V, Degott C, Erlinger S, Rueff B, Valla DC, Degos F: Cigarette smoking and hepatic lesions in patients with chronic hepatitis C. Hepatology 200I, 34: $121-125$.

58. Suzuki A, Lindor K, St Saver J, Lymp J, Mendes F, Muto A, Okada T, Angulo P: Effect of changes on body weight and lifestyle in nonalcoholic fatty liver disease. I Hepatol 2005, 43: 1060-1066.

\section{Pre-publication history}

The pre-publication history for this paper can be accessed here:

http://www.biomedcentral.com/1471-2261/7/1/prepub
Publish with BioMed Central and every scientist can read your work free of charge

"BioMed Central will be the most significant development for disseminating the results of biomedical research in our lifetime. "

Sir Paul Nurse, Cancer Research UK

Your research papers will be:

- available free of charge to the entire biomedical community

- peer reviewed and published immediately upon acceptance

- cited in PubMed and archived on PubMed Central

- yours - you keep the copyright
BiolMedcentral 